\section{Toward achieving diversity through collaborative planning in mixed-use precincts: A case study of Florida Road, Durban (South Africa)}

\section{Desiree Cele \& Lovemore Chipunga}

http://dx.doi.org/10.18820/2415-0495/trp68i1.1

Peer reviewed and revised

\begin{abstract}
Entertainment precincts are typically packed with a dynamic mix of people and land uses that create areas with economic and social benefits. However, for a naturally occurring precinct such as Florida Road, Durban, the social disharmony emanating from the placement of the land uses makes the area vulnerable. The aim of the research was to examine how best a collaborative approach could foster diversity. Both quantitative and qualitative primary data, collected by means of questionnaires and interviews drawn from the various stakeholders in the precinct, were conducted in order to assess the nature of the issues. The research also drew data from the lived experience of temporary/long-term residents and visitors and/or users of the precinct to maintain an inhibited view outside of the private interests involved. The research found that there have been minor changes to the spatial land-use pattern since 2007 . There is, however, a higher intensity of land-use activity such as restaurants operating as nightclubs at close proximity to residential flats. The study results showed that, while the Florida Road precinct management has made great progress since its inception in 2012, there is dialectic tension between the relevant stakeholders relating to planning and the decision-making processes. The authors recommend intimate collaborative planning that enables communities and local government to communicate effectively without squandering opportunities to diversify mixed-use precincts.
\end{abstract}

Key words: Entertainment precinct, diversity, collaborative planning, communicative planning theory

\section{DIE BEREIKING VAN DIVERSITEIT DEUR GESAMENTLIKE BEPLANNING IN GEMENGDE GEBRUIKSBUURTE: 'N GEVALLESTUDIE VAN FLORIDA ROAD, DURBAN (SUID-AFRIKA)}

Vermaaklikheidsbuurte is tipies verpak met 'n dinamiese mengsel van mense en grondgebruike wat gebiede ekonomiese en maatskaplike voordele bied. Maar vir 'n natuurlik-aangetrefde buurt soos Florida Road, Durban het die sosiale disharmonie wat voortspruit uit die plasing van die grondgebruike, die gebied kwesbaar gemaak. Die doel van die navorsing was om te ondersoek hoe die beste van 'n gesamentlike benadering diversiteit kan bevorder. Beide kwantitatiewe en kwalitatiewe primêre data ingesamel deur middel van vraelyste en onderhoude onder die verskillende rolspelers in die buurt is uitgevoer ten einde die aard van die kwessies te evalueer. Die navorsing het ook data verkry uit die ervaring van tydelike/langtermyn inwoners asook besoekers en/of gebruikers van die buurt om 'n geïnhibeerde opinie buite die private belange van betrokkenes te verkry. Die navorsing het bevind dat daar geringe veranderinge aan die ruimtelike grondgebruikpatroon sedert 2007 plaasgevind het, maar dat daar 'n hoër intensiteit van grondgebruikaktiwiteit soos byvoorbeeld restaurante wat as nagklubs dien naby woonstelle is. Die studieresultate toon dat, alhoewel die Florida Road buurtbestuur groot vooruitgang sedert sy ontstaan in 2012 gemaak het, is daar dialektiese spanning tussen die betrokke belanghebbendes met betrekking tot die beplanning en die besluitnemingsprosesse. Intieme gesamentlike beplanning wat gemeenskappe en plaaslike regering in staat stel om effektief te kommunikeer sonder vermorsde geleenthede om gemengde gebruikbuurte te diversifiseer, word deur die skrywers aanbeveel.

Sleutelwoorde: Vermaaklikheidsbuurt, diversiteit, gesamentlike beplanning, kommunikasie beplanningsteorie

\section{MALEBANA LE HO FIHLELLA HO SE TSHWANE KA HO SEBEDISA MORERO O KOPANETSWENG DIBAKENG TSA TSHEBEDISO E KOPAKOPANENG KA: THUTO YA MEHLALA YA FLORIDA ROAD, DURBAN (AFRIKA BORWA)}

Ho tlwaelehile hore dibaka tsa boithabiso di tlale batho ba sa tshwaneng le disebediswa tse etsang melemo ya moruo hape le boithabiso ba batho. Le ha ho le jwalo, mabapi le sebaka se leng teng ka thaho jwalo ka Florida Road, Durban; kgutso ha e be teng ka lebaka la ho bewa ha disebediswa lefatsheng leo. Di etsa ho be bobebe hore sebaka seo se senyehe. Sepheo sa dipatlisiso tsena e ne e le ho hlahloba hore mokgwa wa tshebedisanommoho ke ofe o ka etsang hore ho be le ntlafatso. Ho entswe dipatlisiso ka pokello ya dintlha tsa sehlooho tsa lebadi le boleng (quantitative and qualitative) ka mokgwa wa pampiri e nang le lenane la dipotso le ka ho botsa batho ba amehang dipotso sebakeng seo e le ho lekola/ ho lekanyetsa sebopeho sa mathata. Dipatlisiso tsena di entswe hape ka pokello ya dintlha ho tswa ho baahi, le baeti ba nakwana/nako tsohle le/kapa basebedisi ba sebaka seo, ba nang le boitsebelo; hore ba kgone ho baballa pono ya baahi ba sebaka seo; ntle le ditabatabelo tsa batho ba bang ba amehang. Tse fumanweng (diphumano) dipatlisisong di bontsha hore ho bile le diphetoho tse nyenyane mokgweng wa tshebediso ya lefatshe ho tloha ka 2007, le ha ho le jwalo, ho na le ho nyoloha ho matla diketsahalong tsa tshebediso ya lefatshe. Mohlala, direstjhurente tse ding di sebetsa jwalo ka ditlelapo tsa bosiu empa di le haufinyana haholo le difolete tsa bodulo. Tse fumanweng (diphumano) di bontsha hore bolaodi ba sebaka sa Florida Road bo ile ba etsa kgatelopele e kgolo ho tloha qalehong ya bona ya tshebetso ka 2012. Ho na le ho se utlwane ka puo pakeng tsa batho ba amehang mabapi le ketso ya merero le tsweletso ya ho etsa diqeto. Re itshetlehile hodima diphetho tsa thuto ya mehlala (the case study),ho hlokahala morero o kopanetsweng, o fang setjhaba le mmuso wa selehae bokgoni ba ho buisana hantle ntle le ho senya menyetla ya ntlafatso ditshebetsong tse fapaneng tsa dibaka.

Mantswe a sehlooho: Sebaka sa boithabiso, ho se tshwane, morero o kopanetsweng, tsebo ya merero ya puisano

The authors declare no conflict of interest for this title or article.

Ms D.N. Cele, Lecturer, Durban University of Technology, Faculty of Engineering and the Built Environment, Department of Town and Regional Planning, PO Box 1334, Durban, 4000, South Africa. Phone: (031) 373 2673/3045, Email: <Desireec@dut.ac.za> 


\section{INTRODUCTION}

Cities have traditionally been regarded as places of production that facilitate the flow of goods, money and people. Globalisation has changed the role and function of cities; there are also considerable similarities and differences in the experience of cities in the developed and developing world (UN-Habitat, 2011: 6). South Africa's entertainment precincts do have land-use similarities with other American and Australian settings whose cities have promoted cultural hubs/districts or what Florida (2005) dubs 'street level culture' as a way of creating vibrant places with diverse cultures; hence, demographics are very tolerant of difference.

In the South African context, there is a focus on apparent disparities and socio-spatial patterns, stimulated by the recognition of diversity among South African cities. This focus comes with a warning that, if South African cities do not recognise the potential offered by embracing difference and culture, they will miss out on opportunities relating to diversity in this complex, yet multicultural country (Parnell, Pieterse, Swilling \& Wooldridge, 2007). This study is conducted at a time where clarion calls are being made to ensure that all forms of developments being undertaken in South Africa are supposed to make meaningful contributions towards the social transformation of everyone involved.1 Perhaps, in a similar line of thinking as urban activist Jane Jacobs' manifesto The death and life of great American cities and her stance on densification, this research study seeks to promote the various means of embracing a diversity of knowledge and experience in the study area of Florida Road, in the vicinity of the city of Durban.

Florida Road is described as a mixed-use, entertainment-oriented

1 The adoption of the Spatial Planning and Land-Use Management Act (2003) outlines a spatial development vision to address issues concerning land-use management systems; municipal approval periods and planning enforcement and permission as well as disjunctures with existing and newly drawn up planning schemes. corridor whose land uses have changed rapidly from predominantly residential to a variety of uses, mainly retail and entertainment (lyer, 2012). This phenomenon is evident in large municipalities in KwaZulu-Natal, which struggle to deal with the current demand resulting from, among other issues, outdated planning schemes (Robinson, 2014: 266). There is a broad spectrum of potential consequences that accompany outdated planning schemes, making this study relevant to the current debate on the transformation of urban spaces in South Africa.

Between 2009 and 2012, Florida Road has been associated with negative drug-related activities threatening the safety of the community. The establishment of the Florida Road Urban Improvement Precinct management (Florida Road UIP), formed through the collaborative efforts of concerned property owners and business owners, has made notable precinct management changes that have worked successfully. Consequently, the precinct has continued to benefit the city of Durban economically, as the city deals with the enduring legacy of apartheid spatial planning and the movement of business away from the Central Business District (CBD). The study area presents a challenge of, first, bringing the racial and socio-economic groups together to work and live in harmony and, secondly, the ability of the eThekwini local authority to address issues relating to land-use change efficiently.

While there has been considerable research into cultural districts and entertainment precincts as models for the urban revitalisation of downtown areas, with a specific focus on the economic benefits of establishing cultural districts as centres for local economic development (see examples in Seifet \& Stern, 2005; Prinsloo, 2010; Propertuity, 2013; HDA, 2013), there has been limited research that focuses specifically on the urban planning land-use process and the social impact of naturally occurring cultural district models of urban neighbourhoods in a setting with a distinctive history such as South Africa, and research that offers a Social Impact Assessment2 strategy for natural cultural districts as opposed to planned districts.

In such contexts, how can the transformation of South African cities be better understood? In shedding light on this question, this paper attempts to qualify urban transformation by suggesting a planning approach to mixed-use precincts based on notions of Habermas' communicative planning theory and Healey's concept of collaborative planning.

\section{THEORETICAL PERSPECTIVE}

The relevance and value of dialogue has been recognised in the urban development process of contemporary cities. The origins of this realisation in the built environment lie in the theory of communicative action (Habermas, 1984), where actors in society seek to reach a common understanding and to coordinate their actions through reasoned argument, consensus, and cooperation. It is better than strategic action geared towards fulfilling individual needs (Habermas, 1984). The concept of communication has, however, been criticised by Tewdwr-Jones and Allmendinger (1998) who argue that it does not sufficiently take into consideration the role of power and its influence on the participatory process inside and outside the formal system. This argument is in line with Fainstein and Campbell (2012) who argue for different ways of knowing in the collaborative process.

This research is also rooted in Healey's framework of collaborative planning. She explains that it is broader than regulatory land-use planning, as it seeks to resolve some of the wide-ranging critical issues linking knowledge and power that one comes across in the field of planning. These may include general

2 The Social Impact of the Arts Project (SIAP) hosted by the University of Pennsylvania School of Social Policy \& Practice has contributed a number of reports defending Arts and Culture as a sector and its contribution to social and community life. They are now researching 'natural' cultural districts and their implications for cultural district planning Available from: <http://www.sp2.upenn.edu/ SIAP> [Accessed 5 October 2014]. 
power relations; global economic restructuring and its regional impact; environmentalism; technocratic control and the nature of expertise; cultures and systems of governance, and notions of community (Healey, 2003: 101-123).

Collaborative planning acknowledges alternative methods of knowing and reasoning, enabling one to consider different cultural perspectives within spatial planning processes (Healey, 1997). It is a key decisionmaking platform where equity planning is supposed or expected to thrive, because the diverse, participating individuals are represented in some manner. However, role players need to understand the process and their role in order to influence the final decision (Flyvbjerg, 1998). Pieterse (2008: 77) briefly dichotomises Healey's communicative planning perspective and argues that the experience of the cities of the global south is much more complex, since there are evident difficulties in reaching shared values, especially when dealing with vast differences in the interests of the urban elite and those of the urban poor. The authors argue that this very complexity can be best addressed by using collaborative processes in the study area.

According to Innes and Booher (2010: 9), the challenge is to find a way for players to jointly improve their situation rather than to find the best or fairest solution. The Florida Road case makes a relevant contribution to understanding how stakeholder action can be effective if a diversity of knowledge is fostered.

\section{REVIEW OF LITERATURE}

The literature is reviewed in order to establish how the examples highlighted have dealt with these issues in an attempt to validate the need for collaborative effort.

\subsection{The international context}

Internationally, entertainment culture has been successfully used as a catalyst for citywide economic development. In the introduction to her essay (2005), Fainstein describes diversity as a term that has a multiplicity of meanings, as "diversity means a varied physical design, mixes of uses, an expanded public realm, and multiple social groupings exercising their 'right to the city"'. Current urban planners are tasked with fostering diversity in cities. Sandercock (1998: 4) observes: "[T]oday's debates about planning take place in an always contested terrain of race and gender, class and ethnicity, against a backdrop of broader long-term economic and environmental problems". There is also rising social inequality and a myriad of social problems in cities.

A number of influential scholars such as Florida (2002) strongly advocate privileging diversity in cities by attracting what he calls the 'creative class': talented people who share a common interest. Florida (2005: 89) is of the view that "the scale of cities and their diversity of inhabitants create the interactions that generate new ideas". He argues that diverse groups have an ability to create new forms of economic activity, with cumulative benefits for the city in terms of wide-ranging economic growth (Florida, 2002). Contemporary cities are interested in adding cultural and economic value to their cities, which means being competitive in order to achieve 'creative city' status (Landry, 2000; Franklin, 2010). Landry (2000: 335-398) maintains that diversity is the driver of creativity and proposes that cities focus on values such as equity and sustainability, because creativity alone does not guarantee a better quality of life for all. Cities have embraced this notion of diversity by attracting the young, old, male/ female, gay/lesbian, creative, educated, etc., in order to fit into the 'creative cities' agenda (Chen, Orum \& Paulsen, 2013). Chen et al. (2013: 19) state: "[W]e should look at cities not merely as bricks and mortar, buildings and streets ... but also as cultural and social creations providing insight into the ways and customs of the people who live in them". Mixed-use developments typically embody this diversity and experience challenges that are usually area-specific, including the regulation of town-planning schemes, parking provision, long-term financing, and a lack of collaboration between all stakeholders (Sills, 2005: online).

Healey (2010) identifies a different type of diversity, a diversity of knowledge and values which various stakeholders can contribute to a planning project. Inclusionary participatory processes, as an integral part of collaborative planning, examine the challenges pertaining to the involvement of different groups. Healey (2010: 77-80) cites the city of Vancouver, which experienced unregulated growth in the past. Vancouver capitalised on an inclusive planning approach that aimed to connect urban design with existing social circumstances. This benefitted the city and its citizens by making Vancouver identifiable as one of the most liveable cities.

\subsection{The local context}

South African cities have focused on revitalising certain areas that have declined over time for various reasons. Urban regeneration efforts are usually centred on City Improvement Districts (CIDs); these are management tools used to tackle social and economic problems at precinct level (Housing Development Agency, 2013: 10). In Gauteng, revitalisation is deemed essential for the city's long-term sustainability. This requires an understanding that planned mixed-use precincts can foster social cohesion, respond to people's cultural values, and be spaces for the conservation of heritage such as the Freedom Park Heritage Precinct (Prinsloo, 2010: 74-75). However, Long Street in the city of Cape Town Municipality, which has a linear distribution of restaurants, cafes, bars and nightclubs, is confronted by the typical issues of drug-related activities and prostitution (Goga \& Goredema, 2014: 5). While Long Street's history is one of racial exclusion and the street is a very diverse shared space nowadays, this diversity is limited by racially isolated patterns within spaces (Tredoux \& Dixon, 2009: 8-13). Urban transformation goes through various stages at varying scales, visions and projections for a development, but it should not be left to compromise 
livelihoods, as South Africa's past is still deeply rooted in these spaces. As cities take on a shape of mixed uses, land-use change should take people's survivalist needs into account; if not, the problems will either persist or may take on a new form.

The preparation of eThekwini Municipality's Long-Term Development Framework $2010^{3}$ demonstrated these relations, as it involved substantial participation, widening the decision-making process beyond the formal realm of politicians and officials. Any form of involvement in the development process empowers citizens to influence change in their built environment. Integration also promotes synergy between all stakeholders directly or indirectly affected by change.

Collaborative planning becomes a necessary approach in a nation where concepts of justice and equity have directed planners to think progressively about the future of the country. Public participation in the development processes is invaluable, because it aims to ensure that all citizens' voices are heard. This view has been pertinent to South Africa as a democratic and multicultural society with a variety of needs, views and values (Bekker 1996: Preface).

\section{METHODOLOGY}

\subsection{Study area}

The study area is situated in the province of KwaZulu-Natal and forms part of the Windermere area of the city of Durban (eThekwini Metropolitan Municipality). Florida Road is bounded by the suburban areas of Essenwood and Musgrave and is strategically positioned north of the Durban CBD (illustrated in Figure 1).

The Florida Road case study area was chosen for various reasons, including that mixed-use

3 eThekwini Municipality's Long-Term Development Framework 2010 outlines Durban's strategy to fulfil the city's long-term vision 'to become Africa's most caring and liveable city' by 2020 . This plan was formulated in consultation with citizens and the eThekwini Metropolitan Municipality, together with the Imagine Durban project funded by the Canadian International Development Agency (eThekwini, 2010). developments are very topical, as they afford opportunities to all stakeholders: local authority officials, business persons, and residents. Florida Road is one of the oldest streets in the Durban Metropolitan Area. At the end of the $18^{\text {th }}$ century, houses were built along that Road in Victorian and Edwardian architectural styles, thus creating a unique identity for the road. Although the Florida Road area was previously predominantly residential, it has grown organically into a vibrant activity corridor. The precinct has retained its architectural character with a mixed-use zone for residential, office, and commercial buildings. These buildings add value to the urban fabric and carry a particular history and aesthetic quality, which cannot be duplicated.

\subsubsection{Data collection}

Both qualitative and quantitative research methods were used to obtain data from secondary and primary data sources. Secondary data consisted of books, journals, newspaper articles, maps/plans and Internet searches. The data from various sources was used to formulate a theoretical framework and to compile a literature review. Primary data was collected by means of questionnaires specific to individual groups, including openended questions and face-to-face interviews. Questionnaires were administered using various methods such as personal distribution, telephonic contact, and an e-mail survey. Flats were randomly selected and households within each block were also randomly selected, as were individuals within the households, based on who was available at the time of the survey.

In-depth, face-to-face interviews were also held with stakeholders (municipal officials, resident/property owners, and the Florida Road UIP manager). These interviews included 10 open-ended questions, where stakeholders outlined their roles and offered their perspectives and approaches on some of the key issues currently facing the precinct. The participants were debriefed in order to ensure that the interview questions were clear and understood.

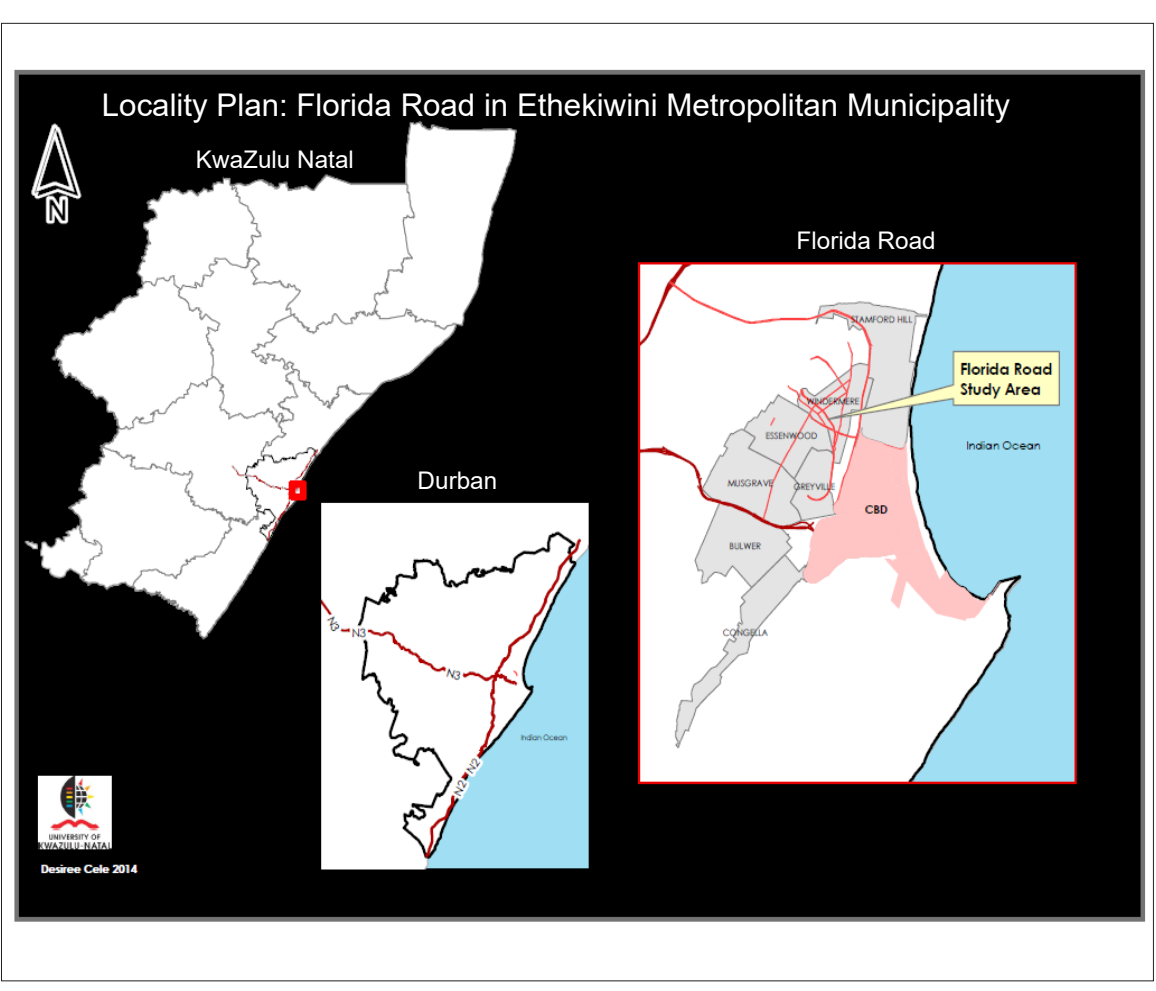

Figure 1: Locality map

Source: Author (2014) 


\subsubsection{Sampling}

Survey participants were selected by means of a random cluster sampling technique. A sample size of $66^{4}$ was chosen to be representative of Florida Road, including available stakeholders. The authors used a stratified random sample where $45 \%$ of the respondents represented residents; $37 \%$ were visitors/users; $16 \%$ represented businesses, and $2 \%$ represented the church(es).

The pertinent stakeholders were identified as follows. Residents are categorised as temporary (renting); permanent (5 years and more) and/or property owners; local businesses (offices/retail/commercial/ entertainment); the church; eThekwini Metropolitan Municipality as the enforcer of planning permission and responsible for the maintenance of infrastructure and the provision of services, and the Florida Road Urban Improvement Precinct (UIP), funded by the Florida Road commercial landlords and property owners (The Florida Road UIP, 2013: online). Other participants included visitors/users understood as people who live outside the study area, but utilise the space temporarily either for work purposes or for leisure.

\subsubsection{Data analysis and interpretation of findings}

A Likert-scale measurement (opinion testing) method was used to analyse the results of the survey. The simplicity of this instrument made it particularly useful for longitudinal assessment of the most valued/ important feature on Florida Road, on a 4-point Likert-scale assessment, where $1=$ Not important and 4 = Most important (refer to findings in Figure 4). The values assigned to each response are as follows:

$$
\begin{array}{ll}
\text { Not important } & =1 \text { point } \\
\text { Least important } & =2 \text { points } \\
\text { Important } & =3 \text { points } \\
\text { Most important } & =4 \text { points. }
\end{array}
$$

4 The research study was conducted as part of a requirement for the Master of Town \& Regional Planning Short Dissertation with limited funding; the sample size was deemed large enough to observe a significant effect, but it can be hypothesised that, in case of increasing sample size, there would not be much difference, as the result would retain the characteristics of the findings.

\section{FINDINGS}

\subsection{Study area land-use analysis}

Figure 2 shows that Florida Road has a range of compatible and non-compatible land uses, all within walking distance. The Road is characterised by both horizontal and vertical mixed uses.

The northern portion of the precinct (Cluster 1: Residential/office/ commercial) is predominantly residential, with offices offering professional services, shops, restaurants, and a nightclub towards Lambert Road. Cluster 2 has predominantly mixed-use land uses in the form of entertainment/ retail/commercial activity. Cluster 3 has changed in terms of the types of commercial land uses; there are three lounges, which were previously restaurants, all in the same vicinity as residential flats. St Joseph's Catholic
Church on Gordon Road, which falls under Cluster 2, and a hotel (The Benjamin Hotel), found in Cluster 3 , remain traditional staples on Florida Road and there is an additional church, the Olive Tree Church on Seventh Avenue on the lower position of the precinct. When comparing the 3 clusters, Cluster 3 has a tighter mix of flats/restaurants/lounges.

\subsection{Demographic profile of respondents}

The questionnaire for both the residents and the visitors required the respondents to provide basic demographic data, including age, gender, occupation, education, and household income. The questionnaire, therefore, solicited information on the respondents' gender and age. Of the residents and visitors/users surveyed, $62 \%(n=45)$ of the respondents are male, while $38 \%$ are female.

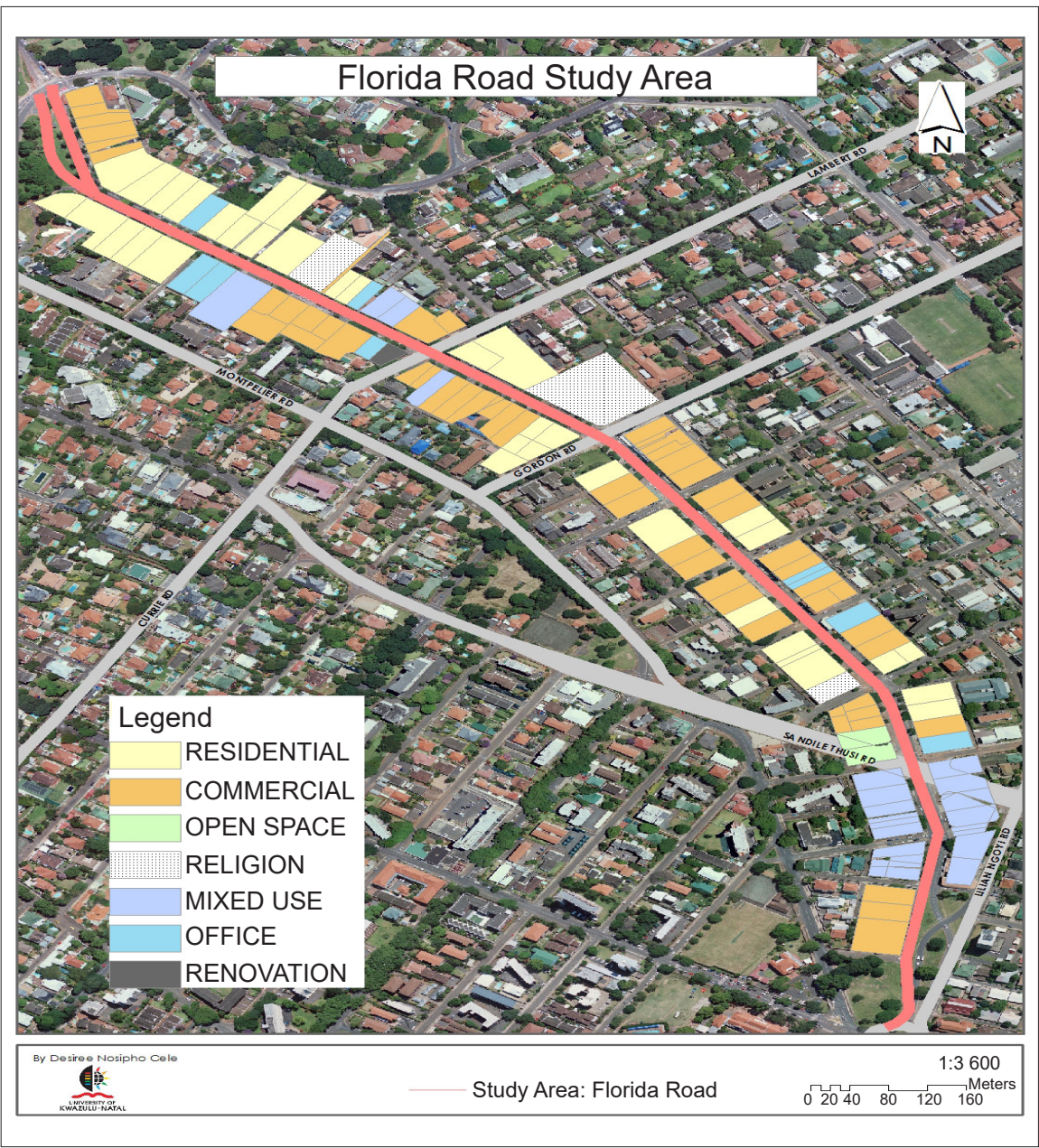

Figure 2: Existing land-use plan of Florida Road

Source: Author (2014) 


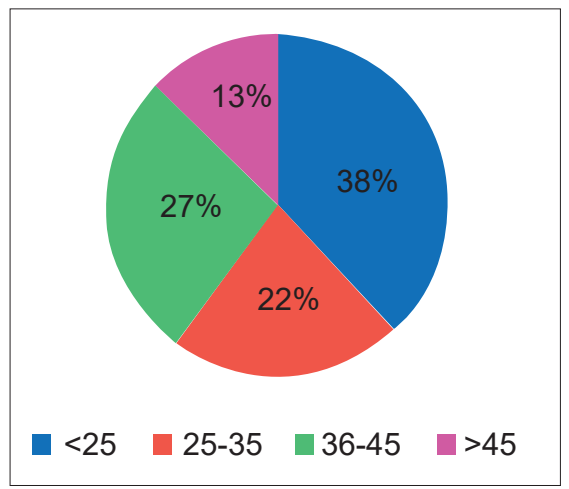

Figure 3: Age distribution of respondents

Figure 3 shows that $38 \%$ of the respondents surveyed fell within the 'under 25' age group; $27 \%$ of the respondents surveyed fell within the $36-45$ age group; $22 \%$ were $25-35$ years old, and $13 \%$ were over the age of 45 .

Out of the visitors surveyed, $60 \%$ fell into the age group of 'under 25'; $40 \%$ were $25-45$ years, while none of the visitors surveyed were over the age of 45 . Although one can only speculate about the differences, several explanations are plausible such as: Florida Road attracts younger visitors and the residents who are also property owners are older.

\subsection{Socio-economic perspective}

The Florida Road corridor is surrounded by a transport network, linking it directly with the Durban CBD. This and a variety of other factors have made the Road attractive to all the stakeholders, property owners and a lucrative location for business, ${ }^{5}$ especially because the Road plays a prominent role in the tourism sector and performs a citywide function within the metropolitan area (lyer, 2012).

For the residents, it was the 'locational' factor, because the area is embedded in a good road network; this was followed by the 'popularity of the area'; 'the mix of people'; 'living quality'; 'networking', and 'coincidence'.

The precinct presents identifiable social and economic classes. There is a relatively small informal (nontaxpaying) business sector in the

5 The majority of businesses operate between the hours of 7:00 and 23:00. form of street traders and car guards. Ethnic-economic diversity can also be attributed to the varied employment opportunities (formal and informal) in the area. For example, some car guards are immigrants from various African countries.

The precinct also attracts many visitors, but it is also home to longterm residents and property owners. Of the respondents surveyed, $90 \%$ had lived in the area for less than five years and of these, only $30 \%$ had resided there for less than a year. $10 \%$ of the residents had lived in the area for five years mainly because of the 'location and atmosphere'; all of the respondents favoured the 'vibe/ experience' that Florida Road offers.

Asked if they have noticed any changes in the 'appearance and function' of the road since 2012, 5\% of the respondents $(n=57)$ answered 'no'; the precinct still looks the same, while $95 \%$ answered 'yes'; the positive changes cited included the cleanliness of the street, signage, and landscape maintenance.

Responses on negative changes were revealed among all resident respondents $(n=20)$; the reasons cited included a high level of theft (especially of cars); noise pollution, and the overall nuisance caused by evening activities, particularly the impact of restaurants/lounges/ nightclubs during weekends and at month end. A resident interviewee further expanded on this and alluded to the issue of restaurants operating longer than the hours permitted in the evenings. There is a sense of disapproval with nightclubs (or similar activity) operating outside of their permitted operation time, or restaurants which, after a certain time in the evenings, operate as would a nightclub.
The negative land-use conflict and associated behaviour are not unique to South Africa's entertainment precincts such as Florida Road; there is evidence of a variety of issues found in Canadian and Australian entertainment precincts (see examples in Walljasper, 2007; Burke \& Schmidt, 2009; Mcllwain \& Homel, 2009; Corporate and Community Planning, 2010: 11-20; Hansen Partnership, 2013: 4-33). What makes the Florida Road situation tense is that, for the residents, there is diminishing confidence in eThekwini Municipality's ability to be responsive let alone proactive, and that little attention has been paid to how this makes the Road vulnerable to losing its value as a once prominent residential area.

The authors questioned whether this outlook has influenced the residents' perception of the quality of life in the study area; the variables used to assess this are illustrated in Figure 4.

It is interesting to note that the respondents placed the historical character of the area as the second valued feature. A member of the eThekwini Municipality's Urban Design and Landscape Planning section advised that, while it may be worthwhile to conserve historical buildings, it is also important to encourage the integration of current culture (modern architecture) in a manner that works well for all rather than the individual.

\subsection{Public engagement}

In order to avoid confusion, public engagement was divided into two components, namely community engagement between the Florida Road UIP, the residents and businesses, and the eThekwini Municipality's public participation with

Figure 4: Most valued feature on Florida Road?

\begin{tabular}{|c|c|c|c|c|c|}
\hline \multirow{3}{*}{ Indicators of quality of life } & \multicolumn{4}{|c|}{ Response $(\mathrm{N}=20)$} & \multirow{3}{*}{ Ranking } \\
\hline & \multicolumn{4}{|c|}{1 Not important ............. 4 Most important } & \\
\hline & 1 & 2 & 3 & 4 & \\
\hline A good place to live & 6 & 12 & 2 & 0 & 3 \\
\hline Historical character of the area & 0 & 4 & 12 & 2 & 2 \\
\hline Access to shops/restaurants & 0 & 0 & 4 & 16 & 1 \\
\hline Public transport system & 14 & 6 & 0 & 0 & 4 \\
\hline
\end{tabular}

The average $(n=54)$ is 2.6 . 
the key stakeholders of the Florida Road precinct.

\subsubsection{Community engagement}

In an interview, Florida Road UIP manager outlined that the UIP has played a key role in facilitating active community engagement through public meetings, to which all residents and businesses in the area are invited. Residential/property owners' input through their involvement has helped clarify what they would like to see happen in the precinct, particularly in respect of any precinct management changes. Respondents were asked if they want to be notified of any management changes. ${ }^{6}$ All the business respondents $(n=11)$ answered "Yes". Of the resident respondents surveyed, $90 \%$ $(n=20)$ were interested in receiving notification of any changes occurring in the precinct, whereas $10 \%$ did not comment. ${ }^{7}$

\subsubsection{Public participation}

The resident respondents $(n=20)$ were asked to report in each case whether or not ("Yes" or "No") they themselves had engaged with the municipality or been given an opportunity to express opinions on land-use changes over the past 3 years (2012-2014). This aimed to gauge their level of access to municipal information and whether their lack of access can be attributed to a lack of knowledge. The majority of the respondents $(70 \%)$ did not comment on this question. Only $30 \%$ answered "No", which can perhaps be attributed to the method used by the municipality to advertise. The authors find significant associations between accelerated residential dissatisfaction and their unclear role.

The resident respondents $(n=20)$ were then asked if they read newspapers: 80\% answered "Yes", while $20 \%$ did not respond to this question. The question sought to learn how many residents do, in fact, read the newspapers in which the municipality advertises, or publishes

6 In this instance, 'changes' refers to any physical modification/maintenance that impacts them in some way.

7 A response was classified as "No comment" if the respondent made no comment in response to a question. planning-related applications and invites the public to comment. These newspapers include iLanga, The Mercury, eThekwini Metro ezasegagasini, The Daily news, and Highway mail. The results show that the majority of the respondents do not read these newspapers. Most of them answered that they read The Sunday Times and only three said that they read The Mercury.

Those surveyed were also asked if they were happy with the current method of municipal advertising, including notices in newspapers, as well as on the property and local authority website. The majority of the respondents surveyed did not answer ${ }^{8}$ the question and replied "Yes". Cross-examination of these results and the results on whether or not the respondents are given an opportunity to make an input, indicates that the majority of the respondents either said "No" or did not give an answer. These responses show that they may not be aware of official planning procedures. Their interest in receiving notifications, to which all the respondents agreed, is, however, an indication that this is perhaps simply a matter of convenience. The respondents were also asked to outline the advertising method that would suit them best.

One of the residents interviewed was asked if he was happy with the current method of advertising municipal notices in newspapers or on the local authority's website. The respondent expressed his unhappiness since, despite their effort to alert the municipality on applications made through the municipality [referring to the Special Consent application ${ }^{9}$ process], there are still businesses operating unlawfully. The respondents were asked to make suggestions on any additional method of advertisement

8 A response was classified as "No answer" if the respondent did not give an answer to a question.

9 "To change the use for which your property is zoned, an application for permission needs to be obtained from the Consent Use Division so as not to compromise the intentions of the Town Planning Scheme. This process assists with the co-ordinated development of the City and protects your health, safety, welfare and the amenities in the area" (The eThekwini Municipality, 2014: online) that suits them and would encourage more participation. The results, however, showed a different perspective, as half of the 20 residents surveyed did not attempt to answer the question. Of those who did answer, eight said that the best method is e-mail alerts, while one opted for a neighbourhood noticeboard and one for the SMS (short messaging service via mobile). However, they added that these methods are preferred only for changes to properties and/or land uses specific to the Florida Road precinct.

The residents were also asked if they had attended any public meetings as part of the municipal public participation process in Florida Road in the past two years. All the respondents had attended Florida Road UIP meeting(s) which is (are) regarded as a public meeting. This finding is consistent with the feedback derived from the interview with the Florida Road UIP manager. However, this does not reflect their attendance at municipal meetings relating to the municipalities public participation process for any change in the land use of properties on Florida Road. The residents' active involvement in Florida Road UIP meetings has resulted in commendable place-making improvements. The involvement and contribution by business and the church community were also taken into consideration.

The business respondents $(n=11)$ were asked if they are active in any neighbourhood organisations; $46 \%$ answered "No"; 36\% answered "Yes", and $18 \%$ did not answer. ${ }^{10}$ Of the $36 \%$ who answered "Yes", they also added that they were involved in both the Florida Road UIP meetings and the Florida Road business committee for the past two years (2013-2014). The findings show that the business community does not have adequate representation at the Florida Road UIP meetings in comparison with the residents.

10 A response was classified as "No answer" if the respondent did not give an answer to a question. 
The land-use management official interviewed mentioned that there are evident capacity and enforcement issues on Florida Road and proposed the need for an area champion assigned specifically to resolve conflict. As far as public participation is concerned, the mechanisms and processes are in place; a 'community participation policy' encourages dialogue with residents together with the cities awareness campaign, which encourages citizens to know their rights.

It is clear that residents and some businesses lack confidence in the municipality's ability to enforce its authority. Reversing this situation requires an understanding of current land-use status and establishing and maintaining a synergistic relationship between land uses, in order to maintain amenity in the precinct. Fortunately, the extent of this disharmony has not yet resulted in the movement of permanent residents (property owners) out of the area. The residents $(n=20)$ were asked if they had considered moving away from the area; half (50\%) of them answered "No", while a third answered "Yes", and the remainder of them did not answer. ${ }^{11}$ The 50\% reluctance to move away means that, despite the residents' concerns, they remain sufficiently committed to remain and be a part of the solution.

The results of this study lead us to confirm the importance of retaining this residential harmony; to build an ongoing relationship between the residents and the business community so as to mitigate the unfavourable effects of living in a tense environment. Perhaps, it is more difficult for those residents who have been part of Florida Road before its face began to change than it would be for residents who were attracted by the very features it represents at present.

\section{DISCUSSION}

The results of the study showed that, in as much as the precinct is made aesthetically attractive, Florida Road

11 A response was classified as "No answer" if the respondent did not give an answer to a question. needs to go a step further in ensuring progress. In this case, diversity is not being achieved, due to a lack of implementation of collaborative planning approaches in the development of a mixed-use precinct such as Florida Road. Nevertheless, in order to achieve this diversity, it becomes important to understand what changes are inevitable, what changes are likely to improve the precinct, and what changes could potentially result in the precinct losing its value.

Based on the respondents' opinions, it is clear that residents have negative feelings towards some business operations and, even more so, with the local authority. While their opinions matter, there remains first, a need for residents to exercise their rights as citizens, which requires them to seek out knowledge particularly of the procedures to be followed. Management in the Land Use department stated that the eThekwini Municipality does recognise and encourage the community to express their views through the Community Participation Policy (EThekwini Metropolitan Municipality 2006: 10). The preamble to this policy states:

The eThekwini Municipality calls
upon all its citizens to exercise
their right to actively participate
in the municipality's affairs to
the fullest of their abilities ... It is
the conviction of the eThekwini
Municipality that its social fabric
reflects a Unity in Diversity and
Diversity in Unity. The harmony
within this diversified unity serves
as a model for other contexts
nationally and internationally.

Secondly, the residents need to be aware of the role of the Land-Use Management section, ${ }^{12}$ which Management explained as "a corrective role because in the recent past, 2008/2009, a shadow scheme was prepared for Florida

12 This refers to the new Durban scheme regulations and maps on which the public was invited to comment from 10 October 2014 to 10 November 2014 [at the time the research was conducted], including attending a series of public meetings. The municipality has consolidated 30 planning schemes into 5 schemes with an aim to offer a flexible range of land-use management tools (eThekwini Municipality Press Release). KZNPDA@googlegroups. com [Accessed: 14 October 2014].
Road without translating it into a proper legislated scheme. This shadow scheme was prepared together with a guideline document (with no legal statement). This was an incorrect mechanism that undermined planning. Upon realising this, the municipality started with an intervention in 2010 called the Urban Core Extensions review accompanied by two precinct plans. Much had to be reworked, as the amenity of the area disappeared; Florida Road had now evolved. It became clear to the municipality that maximising value was important, but also that social issues are a management issue not a land-use issue.

It is apparent that the main issues can be easily identified. First, safety in the precinct; all stakeholders have a common opinion that car guards are the source of crimes such as car hijacking, theft, drug dealing, and vandalism. Secondly, vagrants are also becoming a problem in the evenings. According to Amisi, Bond, Cele, Hinely, Ka manzi, Mwelase, Naidoo, Ngwane, Shwarer \& Zvavanhu (2010: 95), "car guarding - in Florida Road - has always been the turf of the gangsters especially the $26 \mathrm{~s}^{\prime 13}$. The Florida Road UIP has, to date, formalised the car guards and introduced security efforts; this has reduced the number of vagrants significantly from 2012 . Further investigation reveals that some of these vagrants now occupy an abandoned building on East Road, Overport, a few kilometres from the Florida Road. The Roads precinct manager advised that, while precinct management needs to play its part in dealing with such issues, the community also needs to be actively involved.

The responses to the open-ended questions to businesses revealed that they have a level of frustration towards the residents. When asked about the kind of relationship businesses want with the residents and the municipality, when it comes

13 This is a group of gangs in South African prisons. Popularly known as the 'numbers gang', they consist of the 26s, 27s, and 28s. Each group plays a different role. The $26 \mathrm{~s}$ are synonymous with accruing wealth through smuggling. thenumbersgang.weebly.com [Accessed: 22 September 2014]. 
to changes in the neighbourhood that have an impact on their businesses, one of the respondents answered: "If residents have a query, they should send a letter of complaint/concern." Another respondent suggested

\begin{abstract}
establishing a set of rules and regulations that are sensitive to the living standards of businesses such as average sleeping times and latest times for businesses; allow residents to formalise their opinions through the municipality and build a cohesive relationship; investment of municipality and business in structural changes e.g. sound proofing; establish channels of communication for both private and public input.
\end{abstract}

This is an indication that conflict has resulted in some bitterness among the stakeholders. However, some businesses mentioned that "residents must be open-minded". Both the residents and the business respondents (depending on the side of the law on which the business falls) link the aggravation of disputes over competing land uses with the lack of vigour in municipal enforcement, noting that this issue has been ongoing for years.

Without resting all responsibility on the residents, all parties do need to know their roles, but the question is: Who defines these roles and how much influence or power do they have? Innes (1996: 460-472) argues that all stakeholders can be equally empowered; the authors concur that this can be achieved at neighbourhood level; the results from the Florida Road case reflect a keen need from all involved to find a starting point in order to reach a consensus.

Suggestions made by the respondents included:

- The municipality must distribute a newsletter on what is happening in the area;

- There needs to be an identifiable representative of the municipality and the police as well as permanent security;

- The municipality should set up a dedicated mobile police unit, and

- Promote networking to create a crime-free zone.

Such feedback and more

could be useful in a single platform for collaboration that encourages honesty on the part of all stakeholders instead of an overreliance on speculation. Different assumptions make collective action difficult; hence, the need for clearly defined roles. The key element of communicative planning is the idea that the planner and the practice of planning facilitate communicative exchanges between interested parties on matters of common concern, not simply about matters relating to land use, but also about other matters such as their values and experiences that connect people. It is clear that people have different views and the best way to resolve conflicts is communication rationality. Stemming from Habermas' Communicative Action where actors in society seek to reach common understanding and to coordinate their actions by reasoned argument, consensus, and cooperation works better than strategic action geared towards fulfilling individual needs (Habermas, 1984).

Not disregarding the inevitability of power relations that could change the overall outcome, experiential knowledge (residents/community) is just as crucial as insightful expert knowledge (planner); therefore, a cognitive relationship should be maintained to prevent situations where the community is left dissatisfied with planning decisions that do not blend the traditional and contemporary values emanating from the residential experience. This inclusive way of thinking emphasises a shift to focusing on "socially constructed processes engaging experts and stakeholders" rather than overreliance on the planner as the expert (Innes \& Booher, 2010: 5-9). While the Florida Road UIP has been useful in bringing some stakeholders together, problems persist, due to insufficient commitment on the part of all stakeholders.

This suggests a need for mediation in the form of collaborative planning that aims to foster social cohesion through communicative rationality. Although communicative rationality has been criticised for placing too much faith in the agents of communicative action (Rienstra \& Hook, 2006), it would be futile to dismiss collaborative planning efforts on Florida Road based on the fear of different influences.

\section{CONCLUSION AND RECOMMENDATIONS}

It is, therefore, concluded that involving residents in planning is invaluable and should be prioritised very early in the planning process. In cases where social ills are evident, residential input as a constituency that reserves the right to be safe within their environment is invaluable. This should be continually reinforced in city-building strategies, especially cities that aspire to be globally recognised as liveable cities.

In the case of Florida Road, an ideal situation would be a series of public meetings involving all stakeholders. A community-planning advocate would be tasked with helping the Florida Road community determine ways of addressing their management and/or planning-related issues. This advocate would have to take a leadership role in negotiations to reduce land-use conflict; this would also involve being part of the formulation of municipal by-laws in order to ensure that all interests are fairly represented. Such an intervention would assist in ensuring that the state of the precinct does not decline as it did in 2010. There is also a need to determine how the community's interests can be included, not only in municipal bylaws, but also as part of the municipal vision. It is recommended that an intense community engagement process be conducted by means of design and vision workshops; this is a lighter way to build a sense of community, and would enable people to relate their experiences, generating knowledge that could inform planning. It is one way to gain an in-depth understanding of community concerns and priorities.

The lack of collaboration is a perilous factor in an environment that relies on human interaction to thrive. Furthermore, achieving diversity through collaborative planning is based on two factors, namely a strong, common vision formulated 
in partnership with all stakeholders, and no barriers to hinder the public participation process. Ultimately, spaces yield cultural history and personal memories, and create a sense of belonging among the people who occupy them, whether temporarily or for long periods of time. It is for this reason that cultural considerations coupled with people's experiences cannot be ignored in urban planning and policy considerations. South African cities stand to gain much if they take advantage of the diversity of their people, history, and places through enhancing community spirit.

\section{REFERENCES LIST}

AMISI, B., BOND, P., CELE, N., HINELY, R., KA MANZI, F., MWELASE, W., NAIDOO, O., NGWANE, T., SHWARER, S. \& ZVAVANHU, S. 2010. Xenophobia and civil society: Durban's structured social divisions. A report commissioned by Atlantic Philanthropies, by the University of KwaZulu-Natal Centre for Civil Society, 12 July 2010.

BEKKER, K. (Ed.). 1996. Citizen participation in local government. Pretoria: J.L. van Shaik.

BURKE, M. \& SCHMIDT, A. 2009. The death and life of great Australian music: Planning for live music venues in Australian cities. In: Proceedings of the 4th State of Australian Cities National Conference, Perth, 24-27 November: City growth, sustainability, vitality and vulnerability. Perth, Western Australia: Promaco Conventions Pty Ltd (CD-ROM).

CHEN, X., ORUM, A.M. \& PAULSEN, K.E. 2013. Introduction to cities: How place and space shape human experience. Oxford, UK: Wiley-Blackwell.

CORPORATE AND COMMUNITY PLANNING. 2010. Late night liquor licence trading in the Chapel Street precinct: Measuring the saturation levels. Research Paper, April 2010.

ETHEKWINI METROPOLITAN MUNICIPALITY. 2006. Community participation policy: Creating an enabling environment for citizens' involvement in matters of eThekwini Municipality - adopted by Council on 29 June 2006.
ETHEKWINI METROPOLITAN MUNICIPALITY. 2010. EThekwini long-term plan: Building a better city, a better country and a better world for tomorrow. Imagine Durban Project.

FAINSTEIN, S. 2005. Cities and diversity: Should we want it? Can we plan for it? Urban Affairs Review, 41(1), pp. 3-19, September. https://doi. org/10.1177/1078087405278968

FAINSTEIN, S. \& CAMPBELL, S. (Eds). 2012. Readings in planning theory. 3rd edition. Oxford, UK: Wiley Blackwell.

FLORIDA, R. 2002. The rise of the creative class. New York: Basic Books.

FLORIDA, R. 2005. Cities and the creative class. New York: Routledge.

FLYVBJERG, B. 1998. Rationality and power: Democracy in practice. Chicago, Illinois: University of Chicago Press.

FRANKLIN, A. 2010. City life. London: Sage.

GOGA, K. \& GOREDEMA, C. 2014.

Cape Town's protection rackets. Institute for Security Studies (ISS), 259, pp.1-15, August.

HABERMAS, J. 1984. The theory of communicative action. London: Heinemann.

HANSEN PARTNERSHIP. 2013. Re-discover Chapel Street masterplan report prepared on behalf of Stonnington City Council. Rev. F. August 2013 pages 4 \& 33. [online]. Available from: <www.chapelstreet. com.au> [Accessed: 3 October 2014].

HEALEY, P. 1997. Collaborative planning: Shaping places in fragmented societies. London: Macmillan. https:// doi.org/10.1007/978-1-349-25538-2

HEALEY, P. 2003. Collaborative planning in perspective. Planning Theory, 2(2), pp. 101-123. https://doi. org/10.1177/14730952030022002

HEALEY, P. 2010. Making better places: The planning project in the twenty-first century. London: Macmillan. https://doi. org/10.1007/978-1-137-01379-8

INNES, J.E. 1996. Planning through consensus building: A new view of the comprehensive planning ideal. Journal of the American Planning Association, 62(4), pp. 460-472. https://doi. org/10.1080/01944369608975712

INNES, J.E. \& BOOHER, D.E. 2010. Planning with complexity: An introduction to collaborative rationality for public policy. USA, New York: Routledge.
IYER, N. 2012. Berea urban core extension phase 2: Development of a FAP/land-use management framework. Durban: Iyer Urban Design Studio.

JACOBS, J. 1961. The death and life of great American cities. New York: Random House.

LANDRY, C. 2000. The creative city: A toolkit for urban innovation. UK, London: Earthscan.

MCILWAIN, G. \& HOMEL, R. 2009. Sustaining a reduction of violence in the licensed environment, March 2009. Brisbane: Griffith University, Key Centre for Ethics, Law, Justice \& Governance.

PARNELL, S., PIETERSE, E., SWILLING, M. \& WOOLDRIDGE, D. 2007. Democratising local government: The South African experiment. Cape Town: University of Cape Town Press.

PIETERSE, E. 2008. City futures: Confronting the crisis of urban development. Cape Town: University of Cape Town Press.

PRINSLOO, H. 2010. Freedom Park - South Africa's flagship heritage precinct. Essays Innovate, 5, pp. 74-75.

PROPERTUITY. 2013. The Maboneng precinct: Connected, urban, neighbourhood. Property Growth Report 2013. Maboneng 2.0 Shifting Urbanism. [online]. Available from: $<$ www.mabonengprecinct.com> [Accessed: 02 November 2014].

RIENSTRA, B. \& HOOK, D. 2006. Weakening Habermas: The undoing of communicative rationality. Politikon: South African Journal of Political Studies, 33(3), pp. 313-339. https://doi. org/10.1080/02589340601122950

ROBINSON, P. 2014. Future, change and choices: Strategic planning methods for built environment professionals. 2nd edition. Dalbridge: Osborne Porter Literary Services.

SANDERCOCK, L. 1998. Towards cosmopolis. Chichester, England: John Wiley and Sons Ltd.

SEIFET, S.C. \& STERN, M.J. 2005. Natural cultural districts: Arts agglomerations in metropolitan Philadelphia and implications for cultural district planning. Philadelphia, Pennsylvania: University of Pennsylvania. 
SILLS, A. 2005. Good solutions guide for mixed-use development in town centres. North Shore City Council. [online]. Available from: <http://www. mfe.govt.nz/publications/towns-andcities/urban-design-case-studies-localgovernment/mixed-use-town-centres> [Accessed: 15 February 2014].

REPUBLIC OF SOUTH AFRICA (RSA). 2013. Spatial Planning and Land-Use Management Act, Act 16 of 2013.

Pretoria: Government Printer.

TEWDWR-JONES, M. \&

ALLMENDINGER, P. 1998.

Deconstructing communicative rationality: A critique of Habermasian collaborative planning. Environment and Planning A, 30(11), pp. 1975-1989. https://doi.org/10.1068/a301975

THE CHAPELSTREET PRECINCT. [online]. Available from: <www. chapelstreet.com.au/chapel-st-north/> [Accessed: 26 May 2014].

THE ETHEKWINI METROPOLITAN MUNICIPALITY. 2014. City services. [online]. Available from: < http:// www.durban.gov.za/City Services> [Accessed: 14 January 2014].

THE FLORIDA ROAD URBAN IMPROVEMENT PRECINCT. 2013. Why a UIP. [online]. Available from: <http://www.floridaroaduip.co.za/why-auip.php> [Accessed: 14 January 2014].

THE HOUSING DEVELOPMENT AGENCY (HDA). 2013. Reviving our inner cities: Social housing and urban regeneration in South Africa research report. [online]. Available from: <www.thehda.co.za> [Accessed: 24 November 2014].

TREDOUX, C. \& DIXON, J. 2009. Mapping the multiple contexts of racial isolation: The case of Long Street, Cape Town. Urban Studies, 46(4), pp. 761-777. https://doi. org/10.1177/0042098009102128

UN-HABITAT (THE UNITED NATIONS HUMAN SETTLEMENTS PROGRAMME). 2011. Urban patterns for a green economy: Clustering for competitiveness. [online]. Available from: <www.unhabitat.org/publications> [Accessed: 15 February 2014].

WALLJASPER, J. 2007. The great neighborhood book: A do-it-yourself guide to placemaking. A project for public spaces book. Canada, Gabriola Island: New Society Publishers. 